\title{
The Earth Excavation and Support Technology of the Connection Engineering on the both Banks of the River Bridge \\ Ye-Mei ZHOU ${ }^{\mathrm{a}}$, Ya-Yun XIONG ${ }^{\mathrm{b}}$ \\ Wuhan City Polytechnic, Hubei, Wuhan 430064 \\ 381134569@qq.com
}

Keywords: Excavation, Support, Calculation.

\begin{abstract}
The earth excavation and supports technology of the connection engineering on the both banks of The River Bridge have ability the characteristics of deep earth excavation, large area, traffic road surface and underground culvert .The entire foundation pit uses the spu-400larsen steel sheet shutter pile fit retaining and protecting with excavating vertical and the length of Larsen steel shutter pile is 9 meters. The steel shutter pile has $300 * 500 \mathrm{H}$ steel veal long in it The independent rectangle piles caps set up the integrated supporting form for $300 * 500 \mathrm{H}$ steel to supporting. The earth excavation and the project of foundation pit retaining and protecting have been focused on through monitoring in foundation pit mechanical calculation and the experiment effect of the project. It shows that the earth excavation and project of supporting is reasonable.
\end{abstract}

\section{Project Overview}

A connecting engineering of two sides of one bridge, which starts from Hanyang hospital on zoo road in one city and ends with MaYing road in front of the viaduct of river embankment, Is 1.7038 kilometers ,It has 69 bearing platforms, mainly to ZH438,ZH440.,ZH572, Which use the central type $\mathrm{H}$ Structure. All are single rectangular bearing platform by six of $2.5 * 6.5 * 2.5$ meters

The project is mainly in flat plain are. The flood plain and terrace in this area consist of fluvial facies and lacustrine facies, whose height is $20-27$ meters. The physical features of this area are flat and open. And its relative height is less than 1-6meters. The headpiece of field strata consists of Holocene clay, mild clay, sand and screed, etc.

\section{The Design of Foundation Pit Supporting}

According to elevation of geological exploration, all cap embedment depth of foundation targets from 3-4.35meters. Most in foundation excavation scope is miscellaneous fill, under the influence of working platform, carry capacity of road surface and underground culvert, the whole line of foundation pit use. The spu-400 type of Larsen steel sheet pile's length is 9 meters long to support and excavate vertically. The steel sheet pile has the kind of steel wei stare which is $300 * 500 \mathrm{H}$ inside and the independent rectangular pile caps have the type of steel bands which is $300 * 500 \mathrm{H}$ in side.

According to the pit excavation depth, the field engineering geological prospecting, hydro geological condition and surrounding environment, the hierarchy of criteria of this foundation pit engineering is secondary, and the maximum deformation of the supporting structure is lens than $60 \mathrm{~mm}$. Because of the difference of the depth of pile caps excavation, the foundation pit design is decided by the most disadvantageous excavation depths which are $4.5 \mathrm{~m}$.

\section{Refining and Protection of Foundation Excavation}

The process of piling technology of support pile in this project as follow Construction preparation $\rightarrow$ surveying and seating out $->$ the first time earth excavation (the breaking of the surface course and cutting surface and basic level of cement) $->$ the installation of supporting pile $->$ the second time earth excavation $\rightarrow$ base treatment and the excavation of drainage facility $\rightarrow>$ the construction of pile cap $->$ backfill of deep foundation pit projects $->$ the remain of steel sheet pile. Every steel sheet pile of pile cap carries forward in turn in clockwise from one side to another side until steel 
sheet pile of the end of construction.

\section{The First Time Earth Excavation}

The excavation of foundation put uses $1.2 \mathrm{~m}$ (3) hydraulic crawler backhoe shovel. The first time depth of earth excavation is $800 \mathrm{~m}$, which is in favor of the set spacing of steel sheet pile. The earthwork which is excavation is piled up outside the surroundings around foundation pit. Its height is less than $1.5 \mathrm{~m}$, and it will keep working plat form of the machinery of steel sheet pile.

\section{The Setting of Supporting Pile}

The Setting of Supporting Pile. First using the holding component parts penetrates the legs to the part of pitch piles. Every time inserting one part, then hammer it lightly. In the process of piling, for guaranteeing the verticality of supporting piles, use two theodolites control in two directions.

The supporting piles insert at one time. When piling, the location and direction the first and second supporting piles should guarantee accuracy because they can play a part in guide of sample plate. In general, every $1 \mathrm{M}$ needs to get measuring.

The Disposition of Problems in Piling. (1) It's hard to insert when the resistance is too high. The reason is mainly meeting clinker and the resistance is too high, pulling out and hitting repeatedly can be used to go through.

(2)The supporting piles leans when setting: piling in the mollisols, the resistance between piles and sail make the piles easily lean. The correction cutting is to use tail mad wedge-shape piles.

\section{The Second Time Earth Excavation}

After finishing construction of steel sheet pile, excavating $1.2 \mathrm{~m}$ deep. Because the first time earth work is piling around the surroundings of foundation ditch, when excavating the second time, we can use $1.2 \mathrm{~m} 3$ by hydraulic crawler backhoe shovel and 25 tons dump truck pull. All earth work is out. When excavating the quadrangle of earth work, the transformation of steel sheet pile should be specataunlated the end angle of quadrangle is excavated by manual work.

\section{The Supporting Installation of Steel Wai Stare}

1. According to the design of supporting to wai stare and the baiting of the supporting structure, the baiting proceeds in concentrated establish mats.

2. Using 25 tons lorry-mourtde crane and 25 tons platform track transform wai stare and supporting structure from processing factory to site.

3. Before installation, the installing line elevation of wai stare should be transferred on steel sheet pile and snap the line. The controlling of elevation proceeds according to the surface of wai stare.

4. Before the installation of wai stare, the bracket whose material is $300 * 500 \mathrm{H}$ steel should be installed in the quadrangle of steel sheet pile by weld.

5. Put the wai stare hoisting to brackets and welding firmly. And the wai stare need to touch steel sheet pile tightly. The transformation of steel sheet pile when setting it needs to use steel sheet or structural steel to pull and weld firmly pull and weed firmly with wai stare.

6. Finally install vertical support and crossing support. The supporting needs to pull and weed firmly with wai tare.

7. The welding rod use E433, thelength of welding line is full weld, the height of welding line is 6 min.

8. After the end of installation, the welding line should be cheek. Only it is satisfied with design requirements can the earthwork excavation.

\section{The Third Time Earth Excavation}

After the installation of wai stare and supporting and checking and accepting, the third time earth excavation can start. When it is apart $20 \mathrm{~cm}$ from the base pile of foundation pit, the man-made digging hillside is used and clear bottom until elevation of design. Control elevation strictly. Prohibit over breaking of foundation pit strictly. 


\section{The Testing of Foundation Pit (see Table one below)}

Tab. 1 the Testing Form of Supporting of Foundation Pit

\begin{tabular}{|c|c|c|c|c|}
\hline $\begin{array}{c}\text { Serial } \\
\text { number }\end{array}$ & inspection item & allowable deviation & Inspection method & result \\
\hline 1 & basal elevation & $0-20 \mathrm{~mm}$ & surveyors level & qualified \\
\hline 2 & axis offset & $50 \mathrm{~mm}$ & The odolite steel ruler & qualified \\
\hline 3 & $\begin{array}{c}\text { the size of } \\
\text { foundation pit }\end{array}$ & $\begin{array}{c}\text { no less than the } \\
\text { design regulation }\end{array}$ & steel ruler & qualified \\
\hline
\end{tabular}

\section{The Checking Calculation of Bearing Capacity \\ Ersaertial Information}

The depth of foundation piT and the condition of soil texture consider the most disadvantage situation. According to geological exploration report, it knows that. The miscellaneous fill has tiny cohesive force, high active earth pressure, which is the most unfavorable pit in the area of motol and bicycle lane is analyzed about force. And the vertical cantilever supporting of $9 \mathrm{~m}$ long strength steel plate is cheeked integrally. (The parameter in the table two)

Choosing the deepest miscellaneous fill ZH438 foundation pit in motor way as analysis, the analysis of foundation pit is to cut off $0.52 \mathrm{~m}$ pavement structural layer. $(2.22 \mathrm{mc}$ concrete $+0.3 \mathrm{~m}$ water stable layer).But as the basis of even load of foundation pit, it chooses 10PKPA.And dynamic lard is 5KPA.The depth of ZH438, foundation pit is $3.339 \mathrm{~m}$.In this area, the deepest foundation pit is less than $3.5 \mathrm{~m}$. And the depth of supporting of foundation pit is checked by $3.9 \mathrm{~m}$.

Choosing the deepest miscellaneous fill ZH572 foundation pit in bicycle lane as analysis, the dynamic load is $5 \mathrm{Kpa}$.the depth of foundation pit is $3.669 \mathrm{~m}$.In this area, the depth of supporting foundation pit is checked by $3.9 \mathrm{~m}$.

Choosing the depth foundation pit ZH440 as analysis, the dynamic load is $5 \mathrm{kpa}$.The depth of ZH440 foundation pit is $4.316 \mathrm{~m}$, the depth of foundation pit is checked by $4.35 \mathrm{~m}$.

Tab. 2 the Parameter from SP-U400 Type of Lasern Steel Sheet Pile 2

\begin{tabular}{|c|c|c|c|c|c|c|c|c|}
\hline model & \multicolumn{3}{|c|}{ sectional } & $\begin{array}{c}\text { Cross } \\
\text { dimension }(\mathrm{mm}) \\
\text { section } \\
\text { area } \\
\text { S SP-U400 }\end{array}$ & $\begin{array}{c}\text { per linear } \\
\text { mater } \\
\text { area }\left(\mathrm{cm}^{2}\right)\end{array}$ & $\begin{array}{c}\text { per linear } \\
\text { mater area } \\
\text { weight }(\mathrm{kg})\end{array}$ & $\begin{array}{c}\text { yield } \\
\text { strength } \\
(\mathrm{MPa})\end{array}$ & $\begin{array}{c}\text { Cross } \\
\text { sectional } \\
\text { mount of } \\
\text { inertia } \\
\left(\mathrm{cm}^{2}\right)\end{array}$ \\
\cline { 2 - 9 } & 400 & 170 & 15.5 & 96.9 & 242.5 & 76.1 & 345 & 38600 \\
\hline
\end{tabular}

\section{Results from Calculations}

According to the analysis results of pile side resistance to up life by Hubei standard

The safty factor of pile side resistance to up lift $\mathrm{ZH} 438$ foundation pit $=2.53$, satisfied with the standard!

The safty factor of pile side resistance to up lift ZH440 foundation pit $=2.41$, satisfied with the standard!

The safty factor of pile side resistance to up lift ZH572 foundation pit $=2.53$, satisfied with the standard!

\section{Conclusion}

By the analysis of above calculation, all the foundation pit using $9 \mathrm{~m}$, long larsen steel sheet pile 
to the cantilever and support is safe, for increasing safety factor, the $300 * 500 \mathrm{H}$ steel is used to horizontal close steel wailing which doesn't need diagonal bracing and stull in the all around top of the construction steel pile, the technology is proved to be safe, when penetrating the solid bed, the efficiency of construction is high and finish the construction task preferably which is the basis of Interconnect of this bridge before Oct. 2014. And putting forward new technology for the earth excavation and $9 \mathrm{~m}$ long Larsen steel sheet pile construction has great influence on similar project from now on.

\section{References}

[1]Tianqiang Yao, zhenhua shi, The Foundation Pit Precipitation Manual [M], Beijing; China Building Industry Press.

[2]Haibin Wang, Yufeng Li,Some Engineering Insected Reinforcing Cage after Grouting Pile Foundation Construction Technology [J].Construction Technology; 2010(10).

[3]Shaoming Huang, Dazhao Gao, Soft Soil Ground Underground Engineering [M]. Beijing: . China Building Industry Press, 2005.

[4]Shiwen, Tian, Changhai Zhan, Peng Zhao, Coastal shoal Area Soil Rock Deep Foundation Pit Supporting Technology that Portfolio Formation [J].Construction Technology; 2013(8).

[5]Xiangdong Song, A Case of Foundation Pit Supporting Technology Application in Some engineering [J].Construction technology; 2013(6). 